\title{
Polycythaemia in Coal Miners with Chronic Lung Disease
}

\author{
B. W. B. CHAN,* M.B., M.R.C.P.ED.
}

Cummary : The polycythaemic response to hypoxia was studied in 30 ex-coal miners, comprising 14 patients with complicated pneumoconiosis and 16 with chronic non-specific lung disease. A close correlation was found between arterial oxygen saturation and haemoglobin, packed-cell volume, and the red cell mass.

\section{Introduction}

Hypoxia is the most powerful known physiological stimulus to erythropoiesis. In human hig!h-altitude residents (Hurtado et al., 1945) and in patients with congenital cyanotic heart disease (Hallock, 1940) chronic hypoxia leads to polycythaemia in which an increased oxygen-carrying capacity compensates for the reduced arterial oxygen saturation, so that the arterial oxyhaemoglobin concentration often remains normal. However, among patients with chronic lung disease this polycythaemic response to hypoxia has been found to be inconsistent or partially lacking (Wilson et al., 1951). More recently the importance of measuring the red cell mass has been emphasized, as an adequate polycythaemic response may be masked by an increased plasma volume (Shaw and Simpson, 1961).

The present paper reports a study of this response to hypoxia in a group of ex-coal miners with chronic lung disease. Special care was taken to include only those patients whose disease was in a truly chronic and stable state at the time of the study.

\section{Patients and Methods}

Thirty patients were studied. They were male ex-coal miners aged 43 to 68 who attended the M.R.C. Pneumoconiosis Research Unit for the purpose of long-term assessment of their lung disease. Patients with pyrexia, purulent sputum, uncontrolled congestive cardiac failure, or a history suggestive of an acute respiratory infection within the preceding month were excluded from the study. Patients on oxygen therapy other than the use of a portable oxygen set during exertion were also excluded, but one patient who voluntarily discontinued the use of oxygen for three weeks was included.

In order to avoid bias, which may be inherent in selecting patients of known arterial oxygen saturation (polycythaemic patients, because of their plethoric appearance, are more likely to have had arterial oxygen studies performed), it was decided

- Member of Scientific Staff, M.R.C. Pneumoconiosis Rescarch Unit, Llandough Hospital, Penarth, Glam. Present address: Department of Medicine, University of Cambridge.
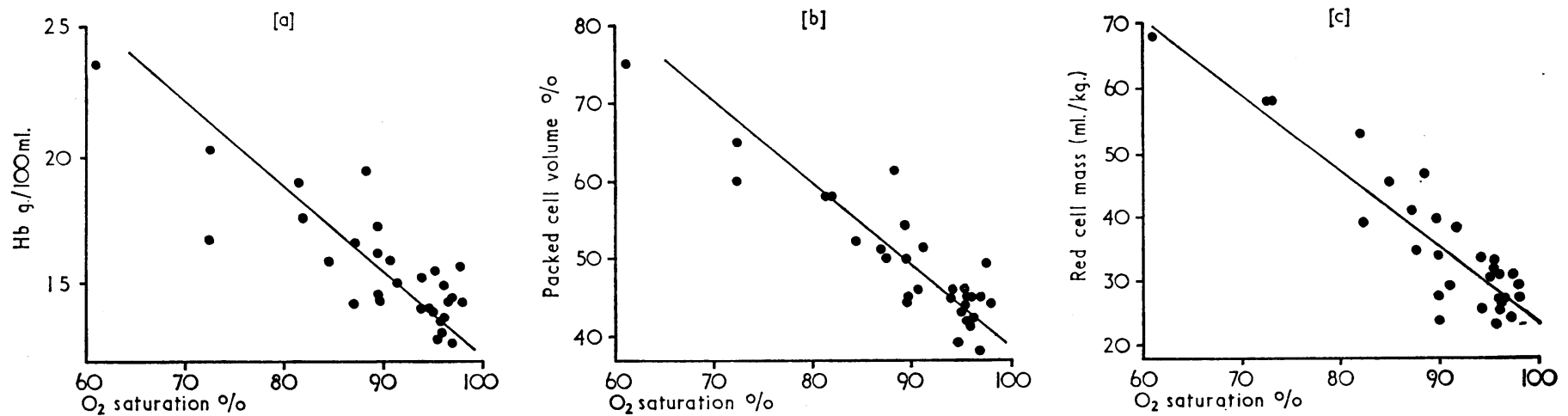

FIG. 1.-Relationships between arterial oxygen saturation and (a) haemoglobin, (b) packed cell volume, and (c) red cell mass. grade $4-5$ according to the M.R.C. bronchitis questionary was used as the selection criteria for inclusion in the study. Thus the group contained the most severely disabled patients seen at this unit, with the omission of those excluded as discussed above.

Of the 30 patients, 14 had complicated pneumoconiosisthat is, they had lung lesions of the progressive massive fibrosis type-an.: 16 had chronic non-specific lung disease (chronic bronchitis and/or emphysema).

Lung function tests, including measurements of ventilation, gas transfer, and lung volumes, were performed in all patients, the standard methods of this laboratory being used (Cotes, 1965). The results serve as physiological description of the patients studied.

Haemoglobin was measured by the cyanmethaemoglobin method. Packed-cell volume was measured by means of a Hawksley microhaematocrit centrifuge. Red cell mass was measured by the method of Sterling and Gray (1950) as modified by Mollison and Veall (1955). Arterial blood was sampled from the brachial artery and analysed for oxygen saturation in a Unicam spectrophotometer by the method of Deibler et al. (1959).

\section{Results}

Results of lung function tests are shown in the Table. The predominant physiological disturbance in the patients studied is that of ventilation. Thus the forced expiratory volume in

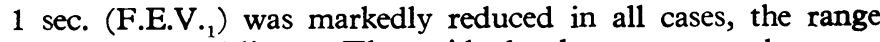
being 0.4 to 1.7 litres. The residual volume, expressed as percentage of total lung capacity, was considerably increased. Changes in the indices of gas transfer were variable ; in some patients these were decreased, probably owing to emphysema. Differences between the two groups of patients were not pronounced. In general the disturbance of lung function in the present series of patients are essentially similar to those in noncoal miners with chronic bronchitis and emphysema who have a comparable degree of disability.

In the relationships between the arterial oxygen saturation and the haematological criteria the regression coefficient has been calculated separately for the two groups of patients, and the differences were not statistically significant ; the results have therefore been pooled. These are shown in the Chart.

Both the haemoglobin and the packed-cell volume were found to be highly correlated with the arterial oxygen saturation, the correlation being slightly better with the packed-cell [b]

to select patients on the basis of disability only. Dyspnoea 


\begin{tabular}{|c|c|c|c|c|c|c|c|c|c|}
\hline \multicolumn{10}{|c|}{ Results of Lung Function Tests } \\
\hline & F.E.V.1 & F.V.C. & T.L.C. & F.R.C. & R.V. & $\frac{\text { R.V. }}{\text { T.L.C. }} \%$ & T.L. & $\mathrm{D}_{\mathrm{m}}$ & $V_{c}$ \\
\hline $\begin{array}{r}1 \\
2 \\
3 \\
4 \\
5 \\
6 \\
7 \\
8 \\
9 \\
10 \\
11 \\
12 \\
13 \\
14\end{array}$ & $\begin{array}{l}0.87 \\
0.60 \\
0.70 \\
0.81 \\
1.70 \\
1.04 \\
1.18 \\
0.75 \\
0.67 \\
0.46 \\
0.74 \\
0.66 \\
0.80 \\
0.68\end{array}$ & $\begin{array}{l}\quad P a \\
1.80 \\
1.60 \\
1.90 \\
2.59 \\
3.30 \\
2.15 \\
1.78 \\
1.50 \\
1.95 \\
1.80 \\
1.95 \\
2.45 \\
1.95 \\
1.50\end{array}$ & $\begin{array}{l}\text { tients wit } \\
\begin{array}{|l|}3.84 \\
3.66 \\
6.46 \\
5.55 \\
5.91 \\
3.97 \\
4.92 \\
4.02 \\
5.65 \\
5.05 \\
4.78 \\
6.58 \\
5.12 \\
3.97\end{array}\end{array}$ & $\begin{array}{l}h \text { Compli } \\
\begin{array}{|l|}2 \cdot 65 \\
2.77 \\
4.45 \\
4 \cdot 15 \\
4.33 \\
2.88 \\
3.11 \\
2.71 \\
3.96 \\
3.82 \\
3.35 \\
4.89 \\
3.34 \\
3.10\end{array}\end{array}$ & $\begin{array}{l}\text { icated } P \\
2.04 \\
2.16 \\
3.24 \\
3.02 \\
2.72 \\
1.84 \\
2.13 \\
2.24 \\
3.20 \\
2.96 \\
2.87 \\
3.94 \\
2.50 \\
2.22\end{array}$ & $\begin{array}{l}\text { neumoconios } \\
\begin{array}{|c|}53 \\
59 \\
50 \\
54 \\
46 \\
46 \\
43 \\
56 \\
57 \\
59 \\
60 \\
60 \\
49 \\
56\end{array}\end{array}$ & $\begin{array}{l}\text { is } \\
14.7 \\
8.5 \\
12.1 \\
14.4 \\
15.6 \\
7.2 \\
18.4 \\
10.4 \\
9.1 \\
13.3 \\
13.0 \\
15.4 \\
15.0 \\
8.7\end{array}$ & $\begin{array}{l}22 \\
13 \\
21 \\
21 \\
25 \\
20 \\
39 \\
19 \\
24 \\
31 \\
25 \\
23 \\
12\end{array}$ & $\begin{array}{l}36 \\
16 \\
25 \\
37 \\
35 \\
9 \\
32 \\
17 \\
13 \\
21 \\
11 \\
36 \\
38 \\
30\end{array}$ \\
\hline iean & & & & & & & $\begin{array}{r}12.56 \\
3.32\end{array}$ & & $\begin{array}{l}25.43 \\
10.68\end{array}$ \\
\hline $\begin{array}{l}15 \\
16 \\
17 \\
18 \\
19 \\
20 \\
21 \\
22 \\
23 \\
24 \\
25 \\
26 \\
27 \\
28 \\
29 \\
30\end{array}$ & $\begin{array}{l}0.80 \\
1.40 \\
0.40 \\
0.65 \\
0.82 \\
0.50 \\
0.73 \\
0.70 \\
0.53 \\
1.00 \\
0.80 \\
0.53 \\
0.53 \\
0.75 \\
0.63 \\
0.50\end{array}$ & $\begin{array}{l}\text { Patie } \\
2.20 \\
2.95 \\
1.80 \\
1.60 \\
2.30 \\
1.70 \\
1.85 \\
1.25 \\
2.80 \\
1.60 \\
2.00 \\
1.20 \\
2.10 \\
2.55\end{array}$ & \begin{tabular}{|l|} 
nts with \\
5.27 \\
3.52 \\
5.55 \\
5.19 \\
6.01 \\
4.22 \\
7.49 \\
3.71 \\
6.17 \\
4.73 \\
5.38 \\
4.71 \\
4.57 \\
6.88 \\
6.16 \\
5.06
\end{tabular} & $\begin{array}{l}\text { Chronic N } \\
\begin{array}{|l|}3.76 \\
2.22 \\
\mathbf{4} \cdot 12 \\
3.72 \\
4.58 \\
2.93 \\
5.69 \\
2.05 \\
4.73 \\
3.28 \\
3.90 \\
3.17 \\
3.10 \\
4.92 \\
3.67 \\
3.62\end{array}\end{array}$ & $\begin{array}{l}\text { Von-spec } \\
\begin{array}{|l}2.30 \\
1.78 \\
2.71 \\
2.75 \\
3.55 \\
2.44 \\
4.87 \\
1.75 \\
3.96 \\
2.33 \\
3.40 \\
2.60 \\
2.57 \\
3.43 \\
2.58 \\
3.41\end{array}\end{array}$ & $\begin{array}{l}\text { ific Lung D } \\
\begin{array}{|c|c}44 \\
50 \\
49 \\
53 \\
59 \\
58 \\
65 \\
47 \\
64 \\
49 \\
62 \\
55 \\
56 \\
50 \\
42 \\
67\end{array}\end{array}$ & \begin{tabular}{|c|} 
isease \\
$8 \cdot 1$ \\
$18 \cdot 6$ \\
13.7 \\
26.7 \\
18.5 \\
10.4 \\
21.0 \\
$16 \cdot 1$ \\
13.7 \\
$19 \cdot 9$ \\
$29 \cdot 1$ \\
$18 \cdot 3$ \\
$14 \cdot 1$ \\
$6 \cdot 7$ \\
$25 \cdot 6$ \\
$12 \cdot 6$
\end{tabular} & $\begin{array}{l}16 \\
24 \\
33 \\
48 \\
16 \\
59 \\
19 \\
17 \\
27 \\
40 \\
50 \\
31 \\
62 \\
20\end{array}$ & $\begin{array}{l}13 \\
56 \\
21 \\
25 \\
22 \\
30 \\
74 \\
26 \\
64 \\
76 \\
24 \\
22 \\
40 \\
31\end{array}$ \\
\hline & $\begin{array}{l}0.70 \\
0.24\end{array}$ & $\begin{array}{l}1.96 \\
0.55\end{array}$ & & & $\begin{array}{l}2.90 \\
0.79\end{array}$ & $\begin{array}{r}54 \cdot 38 \\
7 \cdot 63\end{array}$ & $\begin{array}{r}17.07 \\
6.25\end{array}$ & $\begin{array}{r}33 \cdot 0 \\
5 \cdot 12\end{array}$ & $\begin{array}{l}37 \cdot 43 \\
21 \cdot 10\end{array}$ \\
\hline
\end{tabular}

F.E.V.1 $=$ Forced expiratory volume in 1 sec. $\quad$ F.V.C. $=$ Forced vital capacity. T.L.C. = Total lung capacity. F.R.C. = Functional residual capacity. R.V. Residual volume. T.L. = Transfer factor of the lung for carbon monoxide (ml. min. $/ \mathrm{mm}$. Hg). $\mathrm{D}_{\mathrm{m}}=$ Difusing capacity of the alveolar capillary membrane $(\mathrm{ml}$ in litres.

volume $(r=-0.85$ and -0.90 respectively, $P<0.001)$. The correlation between the red cell mass and the arterial oxygen saturation was nearly the same as that for the packed-cell volume (for red cell mass $\mathrm{r}=-0.91, \mathrm{P}<0.001$ ). Thus haemodilution, which might mask a rise in the red cell mass, did not occur to any significant extent. This finding is of interest because a moderate haemodilution anaemia has been found among coal miners (Chan, 1969), though so far no cases have been found among the severely disabled and hypoxic patients.

These results show a consistent pattern of polycythaemic response to hypoxia. That this is a physiologically adequate response is suggested by the fact that in the patient with the lowest arterial oxygen saturation $(60.9 \%)$ the total haemoglobin concentration of $23.4 \mathrm{~g} . / 100 \mathrm{ml}$. represented an arterial oxyhaemoglobin concentration of $60.9 \times 23.4=14.25 \mathrm{~g} . / 100 \mathrm{ml}$., which is within the normal range.

\section{Discussion}

Since Wilson et al. (1951) reported the apparent lack of polycythaemic response to hypoxia in patients with lung disease, several hypotheses have been put forward in attempts to explain this discrepancy. For example, chronic infection (Wilson et al., 1951), iron deficiency (Fielding and Zorab, 1964), and haemodilution (Shaw and Simpson, 1961) have been suggested as possible causes for the failure of these patients to respond to hypoxia in the normal way. None of these factors, however, seems adequate, when considered singly, to explain the observed discrepancy, though it is possible that they may all play a part.

It is likely that patients in previous studies were in an acute or subacute phase of illness or were convalescent from a recent acute respiratory infection. Thus Tura et al. (1962) found in a high proportion of their patients evidence of active infection, including fever, leucocytosis, raised erythrocyte sedimentation rate, purulent sputum, pathogenic bacteria isolated from sputum, and chest $x$-ray changes suggestive of inflammation. Simpson (1957) pointed out that, whereas the hypoxia of the high altitude resident remains fairly constant, that of the emphysematous patient tends to fluctuate, becoming more severe with a chest infection. Shaw and Simpson (1961) emphasized the need to take the mean of several arterial oxygen saturation readings during the course of a year. Even so, they found that this fluctuated so greatly in three patients of their series that no meaningful average value could be given. These authors also found that increase in the plasma volume which may mask the polycythaemic response tended to occur more often among patients who had recently been in cardiac failure.

More recently the concept of an increased plasma volume masking an adequate polycythaemic response to hypoxia has been challenged (Hume and Goldberg, 1964). Hume (1968) found that in hypoxic patients without congestive failure the plasma volume was below normal. However, these patients were selected on the basis of a high packed-cell volume and were therefore least likely to show a haemodilution effect. He further reported that the red cell mass (calculated indirectly from plasma volume, a direct measurement is more desirable) was significantly correlated with the logarithms of the arterial oxygen tension. This could well be due to the shape of the oxyhaemoglobin dissociation curve in the range studied, and the real correlation is probably with oxygen saturation. This is because, though the erythropoietic stimulus may be ultimately dependent on tissue oxygen tension, this in turn depends on arterial oxygen transport and hence arterial oxygen content.

Further support for this conclusion is provided by a recent series of 73 normal men at sea level and altitudes of 1,600 and 3,100 metres studied by Weil et al. (1968). The red cell mass was found to be correlated with the arterial oxygen saturation throughout the range studied and correlated with the oxygen tension only through that part of the range where the relationship between oxygen tension and saturation is fairly linear. These authors also studied nine patients with chronic lung disease with moderate arterial oxygen desaturation and reported a significant correlation between red cell mass and oxygen saturation. This is similar to the results of the present series in which patients with more severe hypoxia have been included.

In the present study some of the factors causing temporary changes in arterial oxygen saturation and plasma volume have been specifically excluded. This has been made possible because many ex-coal miners with chronic lung disease attend this unit not primarily for the purpose of obtaining medical treatment but to take part in a long-term assessment programme. It was therefore possible to select for study a group of patients whose disease was in a chronic and stable state. From a study of these patients a clear and consistent pattern of a normal polycythaemic response to hypoxia was found.

I thank Dr. J. E. Cotes for advice and Misses A. M. Hall and R. A. Hart for technical assistance.

REFERENCES

Chan, B. W. B. (1969). To be published

Cotes, J. E. (1965). Lung Function: Assessment and Application in Medicine. Oxford, Blackwell.

Deibler, G. E., Holmes, M. S., Campbell, P. L., and Gans, J. (1959). fournal of Applied Physiology, 14, 133.

Fielding

Fielding, J., and Zorab, P. A. (1960) and Medicine, 44, 11 .

Hume, R. (1968). British fournal of Haematology, 15, 131.

Hume, R., and Goldberg, A. (1964). Clinical Science, 26, 499. Hurtado, A., Merino, C.
Medicine, 75, 284 .

Mollison, P. L., and Veall, N. (1955). British fournal of Haematology,

1, 62. 30, 135 .

Simpson, T. (1957). Lancet, 2, 105.

Sterling 1614 .

Tura, S., Pollycove, M., and Gelpi, A. P. (1962). Fournal of Nuclear Medicine, 3, 110 .

Weil, J. V., Jamieson, G., Brown, D. W., and Grover, R. F. (1968). fournal of Clinical Investigation, 47, 1627.

Wilson, R. H., Borden, C. W., and Ebert, R. V. (1951). Archives of Internal Medicine, 88, 581 . 